\title{
E-waste scenario in India, its management and implications
}

\author{
Sushant B. Wath · P. S. Dutt • T. Chakrabarti
}

Received: 25 May 2009 / Accepted: 18 January 2010

(C) Springer Science+Business Media B.V. 2010

\begin{abstract}
Electronic waste or E-waste comprises of old, end-of-life electronic appliances such as computers, laptops, TVs, DVD players, refrigerators, freezers, mobile phones, MP3 players, etc., which have been disposed of by their original users. E-waste contains many hazardous constituents that may negatively impact the environment and affect human health if not properly managed. Various organizations, bodies, and governments of many countries have adopted and/or developed the environmentally sound options and strategies for E-waste management to tackle the ever growing threat of E-waste to the environment and human health. This paper presents E-waste composition, categorization, Global and Indian E-waste scenarios, prospects of recoverable, recyclable, and hazardous materials found in the E-waste, Best Available Practices, recycling, and recovery processes followed, and their environmental and occupational hazards. Based on the discussion, various challenges for E-waste management particularly in India are delineated, and needed policy interventions were discussed.
\end{abstract}

S. B. Wath $(\bowtie) \cdot$ P. S. Dutt · T. Chakrabarti

National Environmental Engineering Research

Institute (NEERI), Nehru Marg, Nagpur,

440 020, Maharashtra, India

e-mail: sb_wath@neeri.res.in
Keywords E-waste management • Best available practices - Environmental and health impact . Developing countries

\section{Introduction}

E-waste and categorization

Electronics industry is the world's largest and fastest growing manufacturing industry. Rapid growth combined with rapid product obsolescence resulted in discarded electronics which is now the fastest growing waste stream in the industrialized world. The growing quantity of E-waste from electronic industry is beginning to reach disastrous proportions. Electronic Waste or E-waste is the term used to describe old, end-of-life electronic appliances such as computers, laptops, TVs, DVD players, refrigerators and freezers, mobile phones, MP3 players, etc. which have been disposed of by their original users. Thus, E-waste is generated out of relatively expensive and essentially durable products used for data processing, telecommunications, or entertainment in private households and businesses.

Technically, electronic waste is only a subset of Waste Electrical and Electronic Equipment (WEEE). According to the Organization for Economic Cooperation and Development (OECD), any appliance using an electric power supply that 
has reached its end-of-life would come under WEEE (EU 2002).

Composition of the E-waste is very diverse and complex. E-waste contains more than 1,000 substances, which can be classified as hazardous and nonhazardous substances. The electrical and electronic equipment can be broadly categorized into following categories (EU 2002):

1. Large household appliances (refrigerator, freezer, washing machine, cooking appliances, etc.)

2. Small household appliances (vacuum cleaners, watches, grinders, etc.)

3. IT and telecommunication equipment (PCs, printers, telephones, telephones, etc.)

4. Consumer equipment (TV, radio, video camera, amplifiers, etc.)

5. Lighting equipment (CFL, high intensity sodium lamp, etc.)

6. Electrical and electronic tools (drills, saws, sewing machine, etc.)

7. Toys, leisure, and sport equipment (computer/ video games, electric trains, etc.)

8. Medical devices (with the exception of all implanted and infected products radiotherapy equipment, cardiology, dialysis, nuclear medicine, etc.)

9. Monitoring and control instruments (smoke detector, heating regulators, thermostat, etc.)

10. Automatic dispensers (for hot drinks, money, hot and cold bottles, etc.)

The waste electrical or electronic equipment include all components, sub-assemblies, and consumables, which are either a part or whole of such products at the time of discarding. The main materials found in electric and electronic waste are ferrous material (38\%), non-ferrous material $(28 \%)$, plastic $(19 \%)$, glass $(4 \%)$, other including wood, rubber, ceramic, etc. $(11 \%)$.

Table 1 shows the average weight and composition of WEEE of selected electronic and electrical equipment commonly used in any household. The various items found in E-waste in different range make the E-waste more diverse and complex in nature (UNEP 2007). However, it shows that Ewaste from these items can be dismantled into relatively small number of common components for further treatment. The materials found in the WEEE can be categorized as hazardous and nonhazardous materials. Table 2 shows the possible hazardous content in the component. The substances within the mentioned components, which cause most concern, are the heavy metals such as lead, mercury, cadmium, chromium (VI), halogenated substances (e.g., CFCs), polychlorinated biphenyls, plastics, and circuit boards that contain brominated flame retardants (BFRs). BFR can give rise to dioxins and furans during incineration. Other materials and substances that can be present are arsenic, asbestos, nickel, and copper. These substances may act as a catalyst to increase the formation of dioxins during incineration (DEFRA 2004).

\section{Indian Scenario: E-waste scenario in India and its management}

The problems associated with E-waste in India started surfacing after the first phase of economic liberalization, after 1990. Due to the stiff compe-

Table 1 Average weight and composition of WEEE of selected EEE commonly used

\begin{tabular}{|c|c|c|c|c|c|c|c|}
\hline Appliances & $\begin{array}{l}\text { Average } \\
\text { weight }(\mathrm{kg})\end{array}$ & $\begin{array}{l}\text { Iron }(\mathrm{Fe}) \% \\
\text { weight }\end{array}$ & $\begin{array}{l}\text { Non-Fe \% } \\
\text { metal weight }\end{array}$ & $\begin{array}{l}\text { Glass \% } \\
\text { weight }\end{array}$ & $\begin{array}{l}\text { Plastic \% } \\
\text { weight }\end{array}$ & $\begin{array}{l}\text { Electronic } \\
\text { component \% } \\
\text { weight } \\
\end{array}$ & $\begin{array}{l}\text { Others \% } \\
\text { weight }\end{array}$ \\
\hline Refrigerators and freezers & 48 & 64.4 & 6 & 1.4 & 13 & & 15.1 \\
\hline Washing machine & 40 to 47 & 59.8 & 4.6 & 2.6 & 1.5 & & 31.5 \\
\hline $\mathrm{PC}$ & 29.6 & 53.3 & 8.4 & 15 & 23.3 & 17.3 & 0.7 \\
\hline TV sets & 36.2 & 5.3 & 5.4 & 62 & 22.9 & 0.9 & 3.5 \\
\hline Cellular phones & 0.08 to 0.1 & 8 & 20 & 10.6 & 59.6 & & 1.8 \\
\hline
\end{tabular}

UNEP E-waste Assessment Manual Vol I (1) Data compiled from Waste from electrical and electronic equipment (WEEE)—quantities, dangerous substances and treatment methods, EEA Copenhagen (2003); (2) QWERTY and EcoEfficiency analysis on cellular phone treatment in Sweden. TU the Netherland (2004) 
Table 2 Possible hazardous substances in WEEE/E-waste components

\begin{tabular}{ll}
\hline Component & Possible hazardous content \\
\hline Cooling & ODS \\
Plastic & Phthalate plasticize, BFR \\
Insulation & $\begin{array}{l}\text { Insulation ODS in foam, } \\
\text { asbestos, refractory ceramic } \\
\text { fiber }\end{array}$ \\
& Lead, Mercury (if coated) \\
Glass & Lead, Antimony, Mercury, \\
CRT & Phosphors \\
& Mercury \\
LCD & Phthalate plasticizer, BFR \\
Rubber & Phthalate plasticizer, Lead, BFR \\
Wiring/Electrical & Lead, Beryllium, Antimony, \\
Circuit board & BFR \\
& Mercury, Phosphorus, Flame \\
Fluorescent lamp & Retardants \\
Thermostat & Mercury \\
BFR-containing plastic & BFRs \\
Batteries & Lead, Lithium, Cadmium, \\
CFC, HCFC, HFC, HC & Ozone depleting substances \\
External electric cables & BFRs, plasticizers \\
Electrolyte capacitors & Glycol, other unknown \\
(over L/D 25 mm) & substances \\
\hline
\end{tabular}

Compiled from WEEE and Hazardous Waste, A report produced for DEFRA (March 2004), AEA Technology

tition in the market of brand, quality, price, and services offered between the various Indian and Foreign companies, the electronic and consumer durable industry grew in India. Also, during the post-liberalization era, due to cheaper rate and increase in the purchasing capacity of the individuals, there was a big boom for the electronic goods industry in India, especially for the home appliances (TV, refrigerator, washing machine, AC, ovens, etc.), telecommunication, IT, and computers. Further, due to infrastructure reforms and e-governance, IT revolution in India is marked by the application of information technology in a big way in all areas. Figure 1 indicates the increase in the sales of PCs in last 8 years during 2001-2009 (MAIT 2008-2009).

According to TRAI, India added 113.26 million new cellular customers in 2008, with an average 9.5 million customers added every month. Cellular market grew from 168.11 million in 2003-2004 to 261.97 million in 2007-2008 (TRAI 2008-09). In 2006, microwave ovens and air conditioners registered a growth of about $25 \%$. Refrigerator sales amounted to 4.2 millions in 2006-2007, and its production went up by $17 \%$ as compared to the preceding year. Washing machines, which have always seen poor growth, have seen reasonable growth in 2006. The penetration level of colored televisions (CTVs) is increased three times by 2007 (NCAER 2007).

These developments, along with indigenous technological advancement, have led to an addition of wide gamut of E-waste churned out from Indian households, commercial establishments, industries, and public sectors into the waste stream. Solid waste management, which is already a mammoth task in India, has become more complicated by the invasion of E-waste, particularly computer waste to India, from different parts of the world (IRGSSA 2007).

So far, the preliminary estimates suggest that total WEEE generation in India is approximately $1,46,180$ tonnes/year which is expected to exceed 800,000 tonnes by 2012 . The top states, in order of highest contribution to WEEE, include Maharashtra, Andhra Pradesh, Tamil Nadu, Uttar Pradesh, West Bengal, Delhi, Karnataka, Gujarat, Madhya Pradesh, and Punjab. The city-wise ranking of largest WEEE generators is Mumbai, Delhi,
Fig. 1 Total PC (Desktops and Notebooks) sales: 2001-2009

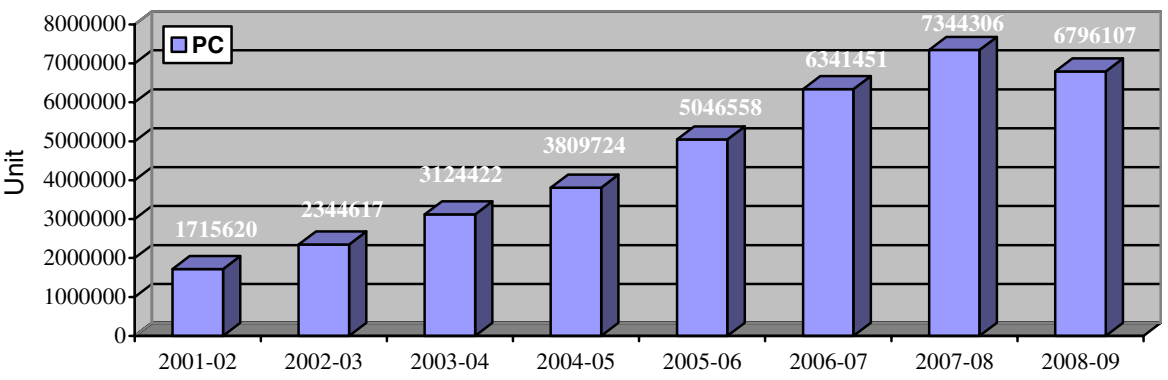




\begin{tabular}{|c|c|c|c|c|c|c|}
\hline $\begin{array}{l}\text { Table } 3 \text { Quantity of } \\
\text { WEEE (Waste Electrical } \\
\end{array}$ & $\mathrm{SN}$ & States & $\begin{array}{l}\text { WEEE } \\
\text { (Tones) }\end{array}$ & $\mathrm{SN}$ & States & $\begin{array}{l}\text { WEEE } \\
\text { (Tonnes) }\end{array}$ \\
\hline Equipment) generated in & 1 & Andaman and Nicobar Islands & 92.2 & 19 & Lakshadweep & 7.4 \\
\hline \multirow[t]{15}{*}{ Indian States } & 2 & Andra Pradesh & $12,780.3$ & 20 & Madhya Pradesh & $7,800.6$ \\
\hline & 3 & Arunachal Pradesh & 131.7 & 21 & Maharashtra & $20,270.6$ \\
\hline & 4 & Assam & $2,176.7$ & 22 & Manipur & 231.7 \\
\hline & 5 & Bihar & $3,055.6$ & 23 & Meghalaya & 211.6 \\
\hline & 6 & Chandigarh & 359.7 & 24 & Mizoram & 79.6 \\
\hline & 7 & Chhattisgarh & $2,149.9$ & 25 & Nagaland & 145.1 \\
\hline & 8 & Dadra and Nagar Haveli & 29.4 & 26 & Orissa & $2,937.8$ \\
\hline & 9 & Daman and Diu & 40.8 & 27 & Puducherry & 284.2 \\
\hline & 10 & Delhi & $9,729.2$ & 28 & Punjab & $6,958.5$ \\
\hline & 11 & Goa & 427.4 & 29 & Rajasthan & $6,326.9$ \\
\hline & 12 & Gujarat & $8,994.3$ & 30 & Sikkim & 78.1 \\
\hline & 13 & Haryana & $4,506.9$ & 31 & Tamil Nadu & $13,486.2$ \\
\hline & 14 & Himachal Pradesh & $1,595.1$ & 32 & Tripura & 378.3 \\
\hline & 15 & Jammu and Kashmir & $1,521.5$ & 33 & Uttar Pradesh & $10,381.1$ \\
\hline & 16 & Jharkhand & $2,021.6$ & 34 & Uttarakhand & $1,641.1$ \\
\hline \multirow{2}{*}{$\begin{array}{l}\text { Country Level WEEE } \\
\text { assessment study by } \\
\text { IRGSSA (2005) }\end{array}$} & 17 & Karnataka & $9,118.7$ & 35 & West Bengal & $10,059.4$ \\
\hline & 18 & Kerala & $6,171.8$ & & Total & $146,180.7$ \\
\hline
\end{tabular}

Bangalore, Chennai, Kolkata, Ahmadabad, Hyderabad, Pune, Surat, and Nagpur. Table 3 shows quantity of WEEE generation in different states in India (IRGSSA 2005).

\section{Present E-waste management system in India}

Most of the activities right from the collection, transportation, segregation, dismantling, etc., are done by unorganized sectors manually. Being a rich source of reusable and precious material, Ewaste is also a good source of revenue generation for many people in India. The big portion (rag pickers) of the Indian population earned their livelihood by collecting and selling the inorganic waste-like plastics, polythene bags, glass bottles, cardboards, paper, other ferrous metals, etc. Figure 2 shows the road map/trade chain of Electronic and Electrical Equipment's journey from manufacture/ importer to recycler/disposer found in most of the Indian cities (MPCB 2007).

In India, most of the operations related to E-waste such as collections, segregation, dismantling, recycling, and disposals are performed manually. In absence of the adequate technologies and equipment, most of the techniques used for the recycling/treatments of E-waste are very raw and dangerous (MPCB 2007). Improper recycling and disposal operations found in different cities of India often involve the open burning of plastic waste, exposure to toxic solders, dumping of acids, and widespread general dumping. As a result, pollutants are dumped into the land, air, and water, which are the cause of serious environmental problems in India. Also, the labors and workers employed in the dismantling and recycling units are poorly literate and uneducated, lacking the basic knowledge about the serious occupational and health risks associated with the operations. Most of the time, dismantling and recycling operations are performed by the workers without proper Personnel Protection Equipment. Mostly hammers, chisels, hand drills, cutters, electric torch/burners, and some time electric drills were used for dismantling the WEEE (MPCB 2007). These operations are carried out in very congested places in the center of cities and slums. Mostly, the dismantling and recycling areas are without any proper lighting and ventilation. In absence of suitable techniques and infrastructure, the workers and laborers working in such areas are prone to serious occupational health hazards (Empa 2004) Thus, there is no organized or formal E-waste management system in India. 


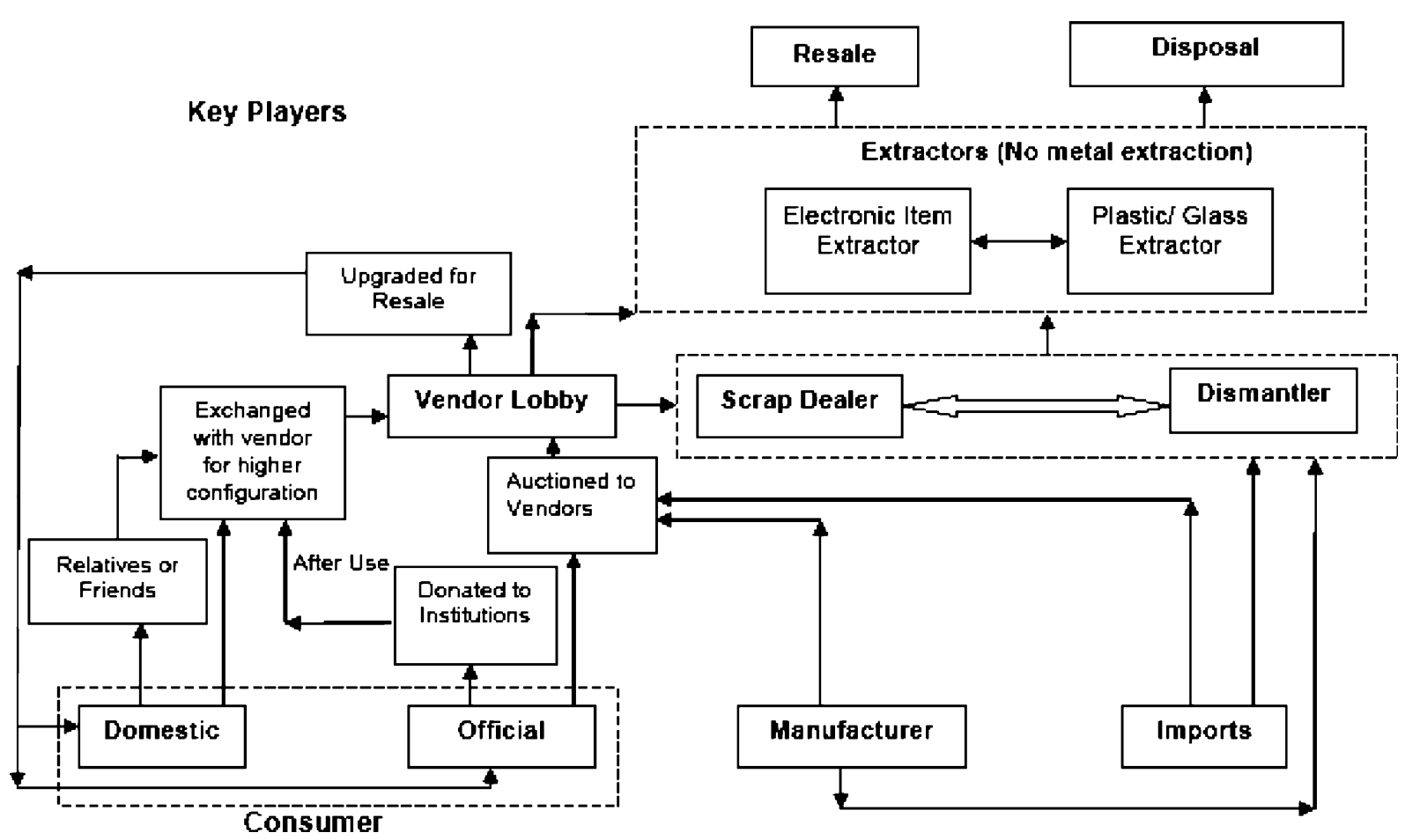

Fig. 2 Flow chart of E-waste trade cycle in India

\section{Global scenario of E-waste management}

Internationally, various legal frameworks have been enacted and enforced to regulate E-waste. The Basel Convention on the Control of Transboundary Movements of Hazardous Waste and its Disposal plays a significant role in curbing the E-waste trade from OECD countries to NonOECD countries. The EU has taken a lead to protect the environment from hazards of E-waste in Europe by framing two important directives, WEEE directive and Restriction of Use of Certain Hazardous Substances (RoHS) in Electrical and Electronic Equipment Regulations directives. Many countries have implemented WEEE Directives (2002/96/EC) with detailed guidelines to assist the producers and consumers in understanding their duty to handle E-waste in environmentally sound manner (EU 2003):

- UK: Waste Electrical and Electronic Equipment, as derived from the WEEE directive, an EU directive, transcribed into UK legislation after being passed by Parliament in
2007. The legislation has put the responsibility of the reporting, financing, and treatment compliance obligations on the operators (private sector) of the producer compliance schemes, instead on each individual producer. Also, the operator is responsible for registering its members with the appropriate national regulator and for providing the details of equipment produced by the members. The producers, preprocessors, and exporters need to get registered with the producer compliance scheme by paying the fee, which can be used as an operational cost for running the scheme. The national regulator fixes the household WEEE quota for each producer compliance scheme. And the operator has to ensure that the WEEE allotted must be treated using best available treatment, recovery, and recycling techniques (Turner and Callaghan 2007).

- USA: US Environmental Protection Agency has initiated a green National Electronics Action Plan (NEAP) to address environmental concerns of electronics. The scope of NEAP is restricted to computers, televisions, and 
cell phones. However, USA have not ratified the Basel Convention. Also, there is no federal legislation in place prohibiting or regulating E-waste generation, disposal, and export. Meanwhile, in the last couple of years, many states in USA have taken efforts for collection and recycling of E-waste from residential and commercial consumers in environmental friendly manner. Fifteen states have introduced the producer responsibility bills. The state of California has introduced a law for collecting the Advance Recycling Fee (ARF) from the consumer at the time of purchase of new product. The system charges ARF ranging from US $\$ 6$ to US $\$ 10$ for electronic items like TVs, laptops, and monitors (Gregory and Kirchain 2007).

Many countries have formulated their own legal instruments for restricting and regulating the hazards of electronic waste.

- People's Republic of China: In China, the electronic waste is regulated by the Administration of Control of Pollution caused by electronic information products (February 2006). Accordingly, the designer and manufactures of electronic information products are required to design and manufacture electronic information products in accordance with the national industrial standards. The administration also provides for penalty for imports, sellers, manufactures, and designer in case of noncompliance. The administration also has provision for penalty on importers, sellers, manufactures, and designer in case of noncompliance of the laid-down standards (Hicks et al. 2005). Table 4 gives the overview of China's national WEEE management-related legislation.

- India: In India, Ministry of Environment and Forests (MoEF) is the national authority responsible for legislation regarding waste management and environmental protection. Although MoEF has approved vide letter no. 23-23/2007-HSDM dated March 12, 2008, the guidelines for environmentally sound management of E-waste with an objective to provide guidance for identification of various sources of waste electrical and electronic equipment

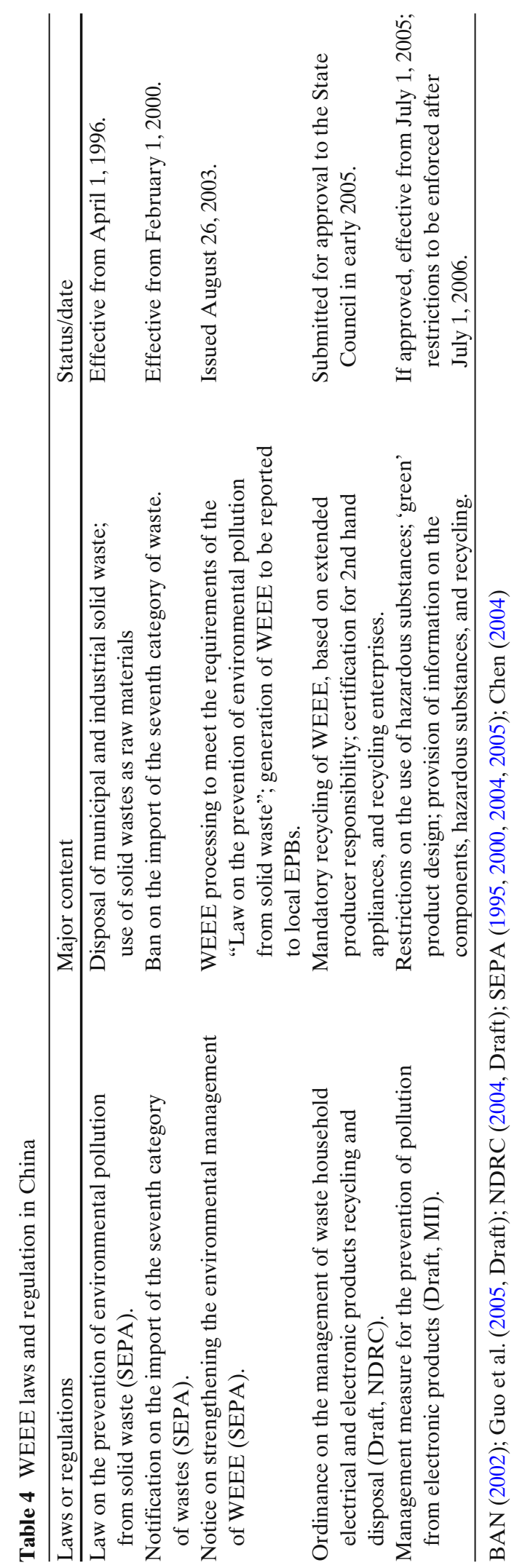




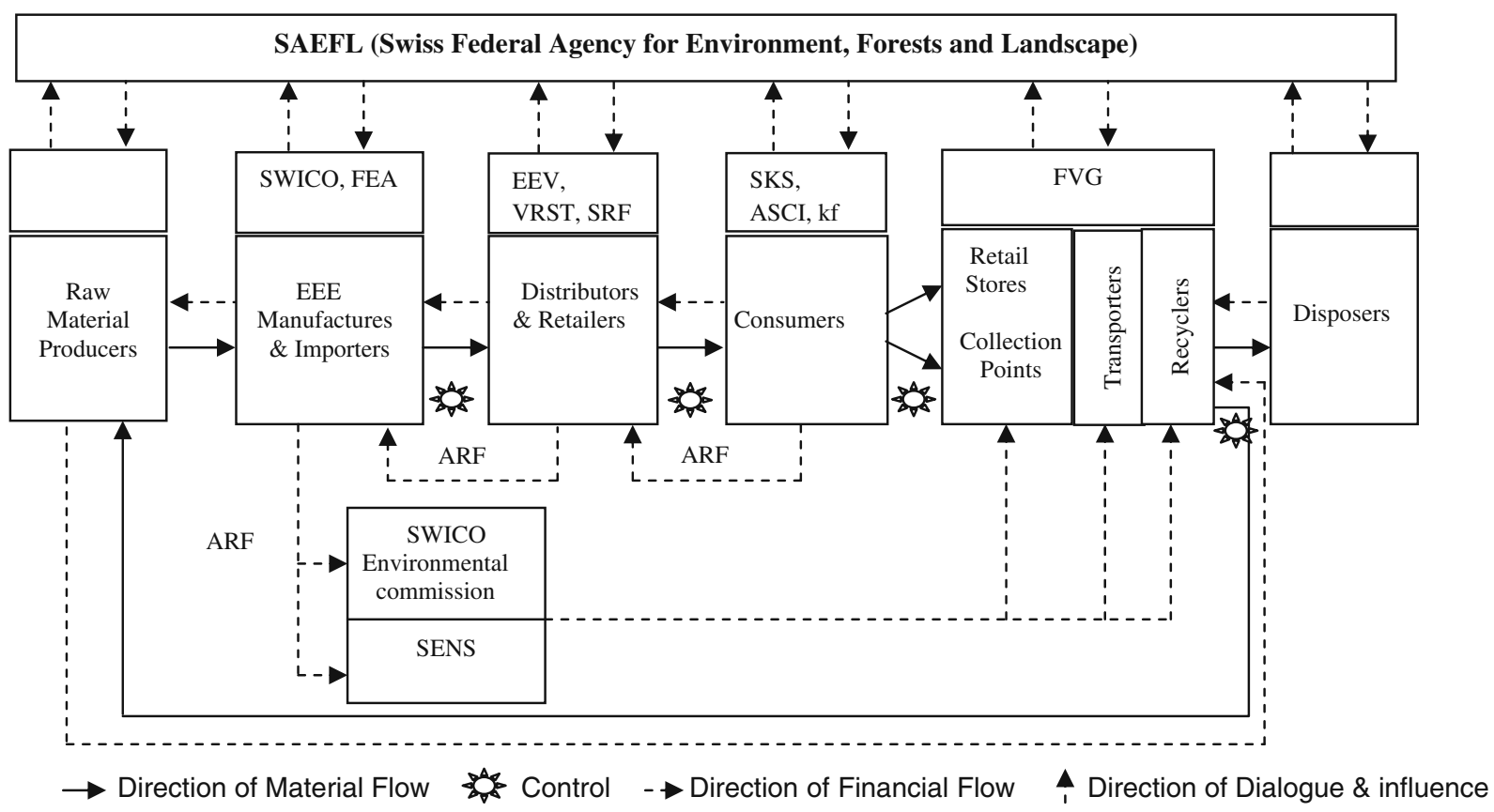

Fig. 3 ARF approach for E-waste management

and prescribed procedures for handling Ewaste in an environmentally sound manner," (MoEF 2008). But there is no law or regulation specifically addressing the E-waste problem (MoEF 2008); however, most of the hazardous material found in the E-waste are covered under purview of "The Hazardous and Waste Management Rules, 2008" under the category of "hazardous" and "nonhazardous" waste.

Management of E-waste is a formidable task and involves multidisciplinary approach. The var-

Table 5 Recoverable quantity of elements in a TV

\begin{tabular}{llcc}
\hline Elements & $\%$ & PPM & $\begin{array}{c}\text { Recoverable Wt. } \\
\text { of element }(\mathrm{Kg})\end{array}$ \\
\hline Aluminum & 1.2 & & 0.4344 \\
Copper & 3.4 & & 1.2308 \\
Lead & 0.2 & & 0.0724 \\
Zinc & 0.3 & & 0.1086 \\
Nickel & 0.038 & & 0.013756 \\
Iron & 12 & & 4.344 \\
Plastic & 26 & & 9.412 \\
Glass & 53 & & 19.186 \\
Silver & & 20 & 0.000724 \\
Gold & & 10 & 0.000362 \\
\hline
\end{tabular}

Compiled from data presented in Cui (2005) ious management methodologies reported in the available literature include segregation, recycle, and recovery options and combinations thereof. However, there is no standard or proven methodology evolved as yet for the management of E-waste. In this context, the best available prac-

Table 6 Recoverable Quantity of Elements in a PC

\begin{tabular}{lc}
\hline Material type & \% Recovered \\
\hline CFCs & 0.20 \\
Oil & 0.32 \\
Ferrous metals & 46.61 \\
Non-Ferrous metals & 4.97 \\
Plastics & 13.84 \\
Compressors & 23.80 \\
Cables/Plugs & 0.55 \\
Spent PurFoam & 7.60 \\
Glass & 0.81 \\
Mixed waste & 1.30 \\
Total & 100.00 \\
Materials disposed of to incinerator & 0.20 \\
Materials disposed of to landfill & 8.90 \\
Materials sent for recovery & 90.90 \\
\hline
\end{tabular}

Compiled from data presented in (1) Exporting HarmHigh-Tech Trashing of Asia. Basel Action Network and Silicon Valley Toxics Coalition, US, 2005; (2) Management of Waste Electrical and Electronic Equipment, ACRR (2003) 
tices of management of E-waste have also been reviewed.

\section{Best Available Practices (BAP)}

- The Extended Producer Responsibility (EPR) is an environment protection strategy that makes the producer responsible for the entire lifecycle of the product, especially for take back, recycle, and final disposal of the product. Thus, the producer's responsibility is extended to the post-consumer stage of the product life cycle. This needs to be included in the legislative framework making EPR a mandatory activity associated with the production of electronic and electrical equipment over a period of time (OECD 2001).

- Switzerland is the first country in the world to have established a formal E-waste management system. The existing E-waste management system based on the ARF approach is given in Fig. 3. The effective collection of E-waste in Switzerland is primarily due to the efficient management of the Ewaste stream by two producer responsibility organizations-The Swiss Association for Information, Communication and Organization
Table 7 Materials recovered from refrigerators
Compiled from data presented in "Waste Electrical and Electronic Equipment (WEEE), Pilot Scheme Report, Producer Responsibility Unit Environment and Heritage Service, Government of UK 2005

\begin{tabular}{|c|c|c|c|c|}
\hline Elements & $\begin{array}{l}\text { Content } \\
\text { (\% of total wt.) }\end{array}$ & Content (g) & $\begin{array}{l}\text { Recycling } \\
\text { eff. (\%) }\end{array}$ & $\begin{array}{l}\text { Recoverable wt. } \\
\text { of element }(\mathrm{g})\end{array}$ \\
\hline Plastics & 23 & 6250 & 20 & $1,250.69408$ \\
\hline Lead & 6 & 1710 & 5 & 85.66368 \\
\hline Aluminum & 14 & 3850 & 80 & $3,083.89248$ \\
\hline Germanium & 0.0016 & 0 & 0 & 0 \\
\hline Gallium & 0.0013 & 0 & 0 & 0 \\
\hline Iron & 20 & 5570 & 80 & $4,454.53312$ \\
\hline Tin & 1 & 270 & 70 & 191.88512 \\
\hline Copper & 7 & 1880 & 90 & $1,696.14576$ \\
\hline Barium & 0.0315 & 10 & 0 & 0 \\
\hline Nickel & 0.8503 & 230 & 0 & 0 \\
\hline Zinc & 2 & 600 & 60 & 359.79072 \\
\hline Tanialum & 0.0157 & 0 & 0 & 0 \\
\hline Indium & 0.0016 & 0 & 60 & 0.26112 \\
\hline Vanadium & 0.0002 & 0 & 0 & 0 \\
\hline Terbium & 0 & 0 & v0 & 0 \\
\hline Beryllium & 0.0157 & 0 & 0 & 0 \\
\hline Gold & 0.0016 & 0 & 99 & 0.430848 \\
\hline Europium & 0.0002 & 0 & 0 & 0 \\
\hline Tritium & 0.0157 & 0 & 0 & 0 \\
\hline Ruthenium & 0.0016 & 0 & 80 & 0.34816 \\
\hline Cobalt & 0.0157 & 0 & 85 & 3.62984 \\
\hline Palladium & 0.0003 & 0 & 95 & 0.07752 \\
\hline Manganese & 0.0315 & 10 & 0 & 0 \\
\hline Silver & 0.0189 & 10 & 98 & 5.037984 \\
\hline Antinomy & 0.0094 & 0 & 0 & 0 \\
\hline Bismuth & 0.0063 & 0 & 0 & 0 \\
\hline Chromium & 0.0063 & 0 & 0 & 0 \\
\hline Cadmium & 0.0094 & 0 & 0 & 0 \\
\hline Selenium & 0.0016 & 0 & 70 & 0.30464 \\
\hline Niobium & 0.0002 & 0 & 0 & 0 \\
\hline Yttrium & 0.0002 & 0 & 0 & 0 \\
\hline Rhodium & 0 & 0 & 50 & 0 \\
\hline Mercury & 0.0022 & 0 & 0 & 0 \\
\hline Arsenic & 0.0013 & 0 & 0 & 0 \\
\hline Silica & 24.8803 & 6770 & 0 & 0 \\
\hline
\end{tabular}


Technology and Stiftung Entsorgung Schweiz (Khetriwal et al. 2005).

- RoHS in the Electronic and Electrical Equipment: There is an increasing trend in the reduction in the use of hazardous substances such as lead, cadmium, mercury, polychlorinated biphenyls, and other toxic and hazardous substances for which safe substitutes have been found. Many countries have adopted the RoHS regulations in the manufacture of electrical and electronic equipment (EU 2002).

\section{E-waste management: implications}

Prospects of E-waste recycling and recovery towards the concept of urban mining

Although there is large amount of E-waste generation in India, there is no systematized or formal system available for handling the E-waste in a scientifically as well as environmental-friendly manner. Large amount of E-waste is being treated and dumped as a municipal solid waste only. Ewaste, being rich in ferrous materials, nonferrous materials, plastic, and precious materials, has turned out as a major business opportunity for many. In the E-waste recycling, mostly manual dismantling is practiced. A variety of tools is involved in the dismantling process for removing the hazardous components and recovery of reusable or valuable components and materials. Mainly the mechanical/ physical recycling process practiced involved screening, shape separation, magnetic separation, electric conductivity-based separation, density-based separation, etc.; techniques depending upon the quantity, type, size, and shape of the material and component in E-waste. Tables 5, 6, and 7 show the recoverable quantity of elements in various WEEE.

Treatment and processing options for E-waste

A versatile E-waste management technology package involving recovery of valuable metals, minimizing environmental and health impacts with demonstration on viable scale needs to be developed.

Mainly the treatment of E-waste is done at three levels. The output of the first is input to the second stage. Environmentally sound E-waste treatment technologies are used at three levels as described below:

1. 1st level treatment

2. 2nd level treatment

3. 3rd level treatment
Fig. 4 Three tire treatment processes for recovery/recycling E-waste

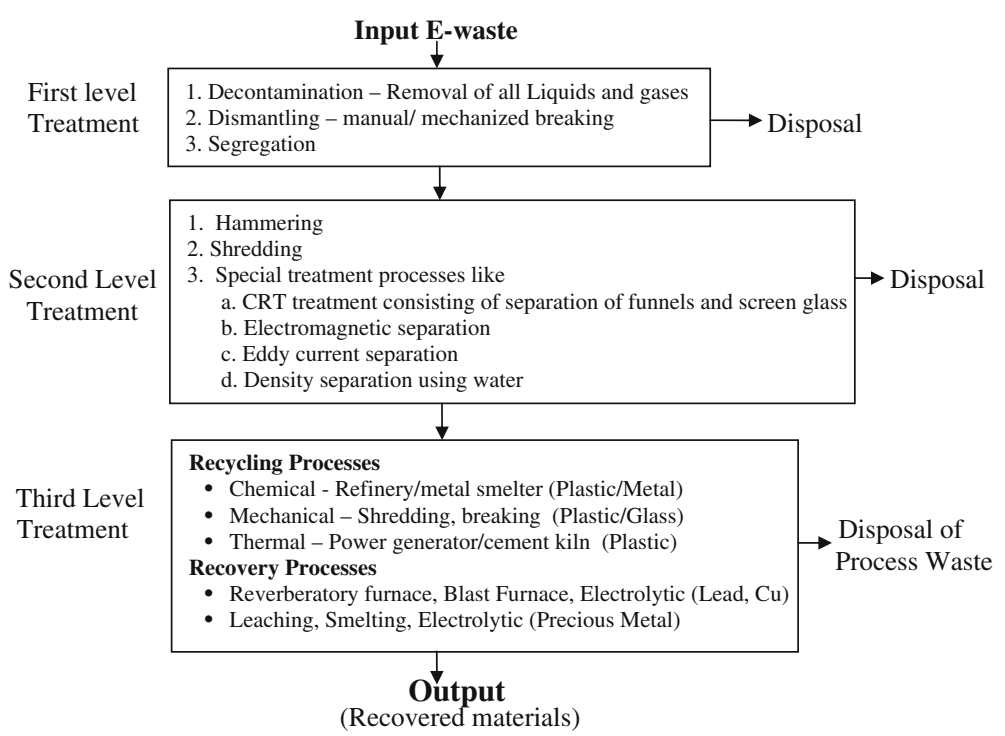




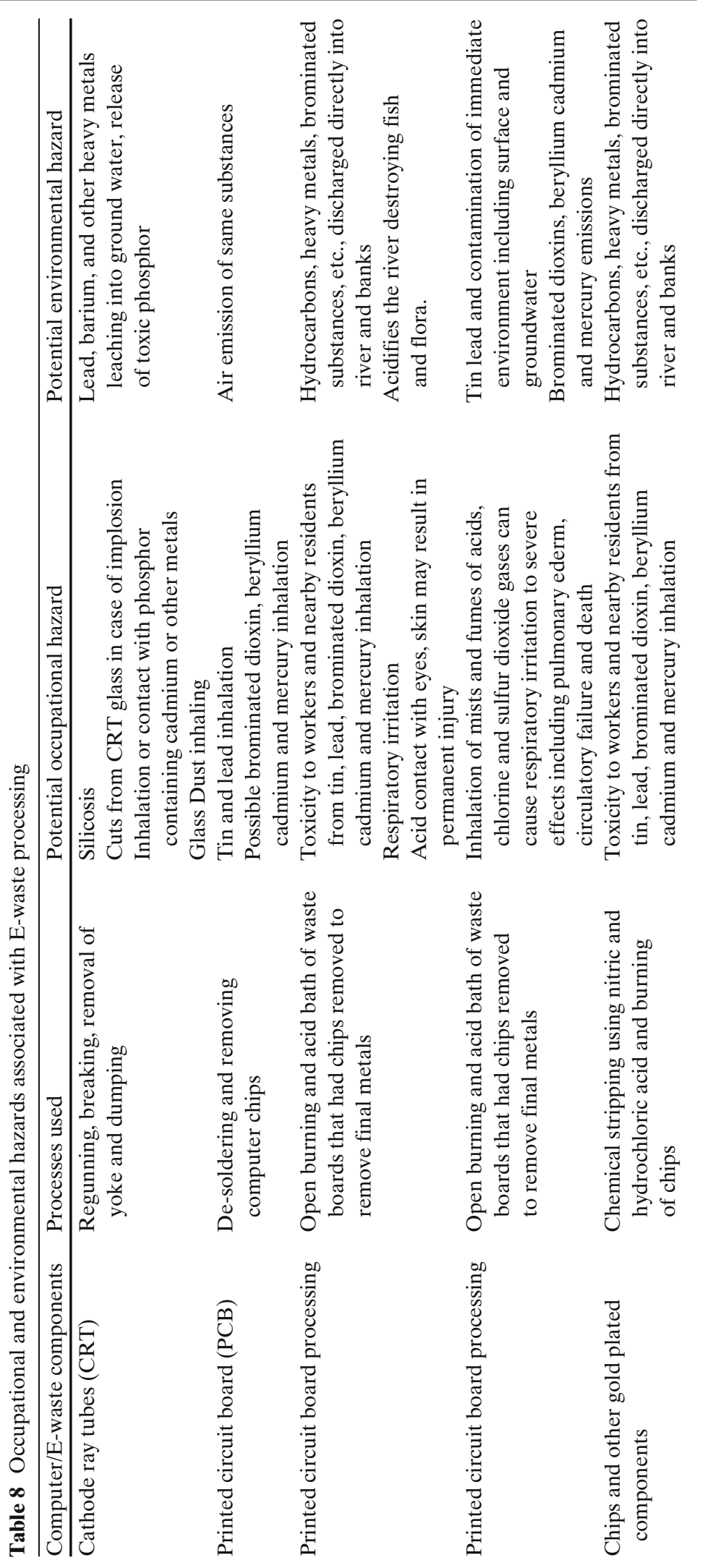



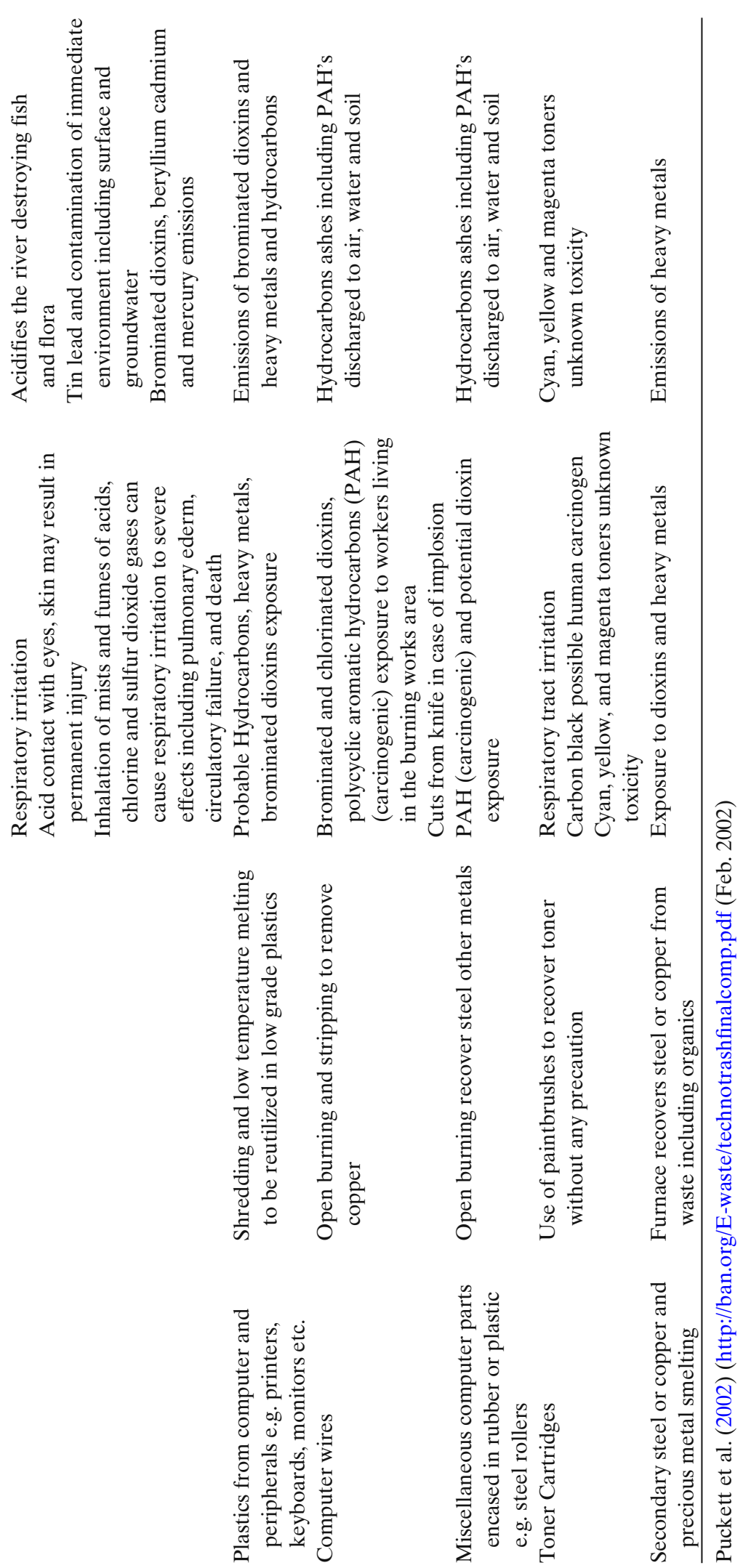
All the three levels of E-waste treatment are based on the material flow. The material flows from 1 st level to 3 rd level treatment. Figure 4 shows the three level treatments. Each level treatment consists of unit operations where E-waste is treated, and output of 1st level treatment serves as input to the next level treatment. After the 3rd level treatment, the residues are disposed of either in hazardous waste Treatment Storage and Disposal Facility (TSDF) or incinerated. The efficiency at 1 st and 2 nd levels determines the quantity of residues going to TSDF or incineration, while the 3rd level E-waste treatment is mostly carried out mainly to recover ferrous, nonferrous metals, plastics, and other items of economic value (Johri 2008).

\section{Environmental and health implications}

E-waste is a serious issue, and in absence of the globally acceptable E-waste definition, its related environmental and health hazards cannot be addressed in a global manner. In India, there is no law or regulation specifically addressed to the E-waste problem; however, most of the hazardous materials found in E-waste are cover under purview of "The Hazardous and Waste Management Rules, 2008" under the category of "hazardous" and "nonhazardous" waste. In most of the Indian cities, E-waste is treated as the municipal waste, and no special attention is given to the activities related to its collection, handling, dismantling, and recycling. Most of the activities related to the E-waste collection, handling, dismantling, and recycling are mainly being performed by the unorganized or informal sectors lacking the technical and infrastructural abilities and knowledge about the serious implications of the E-waste handling and disposal on environment and human health. The environmental impact and health risk associated with E-waste are of very critical and serious in nature leading to degradation and pollution of the natural resources and can lead to chronic diseases in human beings. Due to the hazards involved, disposing and recycling E-waste pose serious environmental and occupation implications. Table 8 lists its associated impacts.

\section{Challenges and opportunities}

Under the scenario, the E-waste management strategy for India has the following challenges, which need to be studied and addressed in more systematic and scientific manner:

Scientific challenges

- Eco-friendly recovery solutions

- Precious metals

- Base metals

- Value addition to recyclables for reuse

- Plastics

- Glass and other recyclables

- Disposal of process waste and residues

- Size reduction

- Toxic reduction

Engineering challenges

- Scientific collection, transport, handling, segregation, and disposal of E-waste

- Integrated/distributed processing facilities

- Unorganized to organized

- Involvement of SMEs and NGOs

- Feasible techno-economical solutions

$\begin{array}{ll}\circ & \text { Processing } \\ \circ & \text { Recycling } \\ \circ & \text { Recovery }\end{array}$

Organizational challenges

- Appropriate definition for E-waste in Indian context

- Inventorization of E-waste generation, import, and its characterization

- Organization and structuring E-waste management system

- Training and awareness on safety, health, and environment

Further, the role and responsibility of the government is very important for developing the Ewaste management strategy for India in terms of transboundary hazardous waste flow, effect of the government policies on employment, in both 
E-waste recycle exporting and importing countries. And as global hazardous waste always flows to destinations with weaker environmental regulations or low economic development, the dirty side of its recycling process would never be properly addressed. The policy should be to design and find out the effective ways to improve job quality in the recycling industry in India, where low-skilled labor is abundant and people are desperate for any income. Any approach should maintain balance between environmental and occupational health along with the economic development.

\section{Conclusion}

The problem of E-waste is growing in alarming proportions in India as also in the world. Although many developed countries have established welldefined E-waste management systems, the systems in India have barriers from socioeconomic, infrastructural, and legal reasons. The E-waste recycling and recovery options practiced in India are very outdated and hazardous, causing severe environmental and occupational hazards. There is a fundamental difference between the current European models of E-waste management and the reality of E-waste recycling in India. There is a need to focus more on levels 2 and 3 treatment systems involving recycling and recovery options for better E-waste treatment and management. At the same time, new initiatives and best practices like ARF and EPR need to be introduced in the country.

Unlike the European E-waste system where consumers need to pay for the disposal of their Ewaste or return them free of charge to recycler, consumers in India, however, expect to receive payment for their E-waste, which is viewed as a potentially valuable resource. Due to which, management of E-waste, if properly carried out, is an opportunity as it is often called as "urban mining." For the environmentally safe treatment and recycling of E-waste, the high initial investment is required for setting facility fitted with technologically advanced equipment and processes. The role of public-private partnership plays a key role in developing and organizing a sound E-waste management strategy in India. Although very few private enterprises have established the facilities for the E-waste treatment in few cities like Bangalore, Chennai, and Noida which are handling and treating the E-waste in more scientific and environmental-friendly manner, more such enterprises need to be established in other cities too.

There is a need for further research and consideration on policy as well as technical level to answer how to adopt and successfully combined the experience and know-how of the existing Ewaste management models from abroad, with the current E-waste system in India, in order to have the formal and well-regulated E-waste Management system for India.

\section{References}

BAN (2002). The Basel Action Network (BAN), the Silicon Valley Toxics Coalition (SVTC), Toxics Link India, SCOPE (Pakistan), Greenpeace China. Exporting harm: The high-tech trashing of Asia. Seattle, WA, and San Jose, CA; February 25th 2002.

Chen, P. (2004). WEEE recycling and legislation development in China. In Conference paper, Electronics Goes Green 2004, 6-8 September, Berlin.

Cui, J. (2005). Compiled from data presented in "Mechanical Recycling of Consumer Electronic Scrap. Licentiate Thesis 2005:36, Luleå University of Technology, Luleå, Sweden." Cui.j.

DEFRA (2004). Department for Environment, Food and Rural Affairs (DEFRA) Report. March $2004<$ www. defra.gov.uk $>$.

Empa (2004). Federal Laboratories for Materials Testing and Research (Empa), E-waste pilot study Delhi: Knowledge partnerships with developing and transition countries. St. Gallen: Empa (http://www.ewaste.ch/).

EU (2002). European Union Waste Electronic Electrical Waste (WEEE) Directive. Brussels: EU.

EU (2003). European Union Waste Electrical and Electronic Equipment (WEEE) Directive. Brussels: EU.

Gregory, J., \& Kirchain, A. (2007). A comparison of North American electronic recycling systems. In Proceedings of the 2007 IEEE international symposium on electronics and the environment (pp. 227-232). IEEE.

Guo, D., Wu, Y., Yu, H., \& Ge, W. (Eds.) (2005). The impact of EU environmental requirements on China (Draft). State Environmental Protection Administration, Policy Research Centre for Environment and Economy and Deutsche gesellschaft fur technische zusammenarbeit (GTZ) GmbH.

Hicks, C., Dietmar, R., \& Eugster, M. (2005). The recycling and disposal of electrical and electronic waste in China- legislative and market responses. 
Journal of Environmental Impact Assessment Review, 25, 459-471. http://www.sepa.gov.cn/eic/649086798147 878912/20031017/1042127.shtml [access date: April 12, 2005].

IRGSSA (2005). Country Level WEEE Assessment study by IRG Systems South Asia Pvt. Ltd. New Delhi: IRGSSA (www.irgssa.com).

Johri, R. (Ed.) (2008). E-waste management, implications, regulations and management in India and current global best practices. New Delhi: Teri.

Khetriwal, D. S., Kraeuchi, P., \& Schwaninger, M. (2005). A comparison of electronic waste recycling in Switzerland and in India. Journal of Environmental Impact Assessment Review, 25, 492-504.

MAIT (2008-2009). Manufacturer's Association for Information Technology Industry performance. Annual Review 2008-09 <http://www.mait.com>.

MoEF (2008). Guidelines for Environmentally Sound Management of E-WASTE. (As approved vide Ministry of Environment and Forestry (MoEF) letter No. 2323/2007-HSMD dated March 12, 2008).

MPCB (2007). Report on Assessment of Electronic Wastes in Mumbai-Pune Area (MPCB report- March, 2007).

NCAER (2007). National Council of Applied Economic Research. India $<$ www.ncaer.org $>$.

NDRC (2004). P.R.C. National Development and Reform Commission (NDRC). Ordinance on the management of waste household electrical and electronic products recycling and disposal (Draft). NDRC Express, September 19, 2004.
OECD (2001). Extended producer responsibility; a guidance manual for governments. Paris: Organization of Economic Co-operation and Development (OECD).

Puckett, J., Byster, L., Westervelt, S., Gutierrez, R., Davis, S., Hussain, A., et al. (2002). A report exporting harm. The High-Tech Trashing of Asia February 25, 2002. http://ban.org/E-waste/technotrashfinalcomp.pdf.

SEPA (1995). P.R.C. State Environmental Protection Administration, Law on the prevention of environmental pollution from solid waste. PRC Presidential Order, No. 58, October 30, 1995.

SEPA (2000). P.R.C. State Environmental Protection Agency. Notification on the import of the seventh category of wastes. SEPA Document 19/2000, 2000.

SEPA (2004). P.R.C. State Environmental Protection Administration. Notice on the environmental management situation of waste electric and electronic products. http://www.crra.com.cn/hykx(36).htm [access date: October 25th, 2004].

SEPA (2005). P.R.C. State Environmental Protection Agency, Notice on strengthening the Environmental management of WEEE; 2003.

TRAI (2008-09). Telecom Regulatory Authority of India. Annual Report 2008-09 <www.trai.gov.in>.

Turner, M., \& Callaghan, D. (2007). Waste electrical and electronic equipment directive, UK to finally implement the WEE directive. Computer Law and Security Report, 23, 73-76.

UNEP (2007). United Nations Environment Programme: E-waste Assessment Manual. 